J. clin. Path., 1976, 29, 42-45

\title{
EB Virus antibody and infectious mononucleosis in a boarding school for boys
}

\author{
T. W. HOSKINS, W. B. FLETCHER, J. M. BLAKE, M. S. PEREIRA, AND \\ J. M. B. EDWARDS \\ From Christ's Hospital School, Horsham, Sussex and the Epidemiology Research Laboratory and \\ Virus Reference Laboratory, Central Public Health Laboratory, Colindale Avenue, Colindale, London NW9
}

SYNOPSIS A study of EB virus antibody was undertaken in a boarding school for boys between 11 and 18 years of age; $35 \%$ of boys had EBV antibody when first sampled and a small number acquired antibody each year. Some of these boys had had no recorded illness during the period before the first positive sample and some developed classic infectious mononucleosis which was accompanied by a positive heterophil antibody test and detection of EB virus specific IgM. In a school of 800 boys there were 13 cases of infectious mononucleosis in four years.

Although information is available about the prevalence of antibody to EB viral capsid antigen (EBVCA) and the incidence of EB virus infection in university students (University Health Physicians and Public Health Laboratories, 1971), little is known about younger people in the UK apart from the study by Pereira et al (1969).

In 1970 an opportunity arose to study antibody to EB virus in the residents of an independent boarding school for 800 boys aged 11 to 18 years. A long-term study of the efficacy of influenza vaccines had been set up which entailed collection of serial sera. These sera were made available for the EB virus study. All boys in the school were under medical surveillance during term time, and any illness resembling infectious mononucleosis was studied by the school medical officer. The criteria for the diagnosis of infectious mononucleosis were similar to those laid down by Evans (1969). They were:

Clinical:

Sore throat, fever, lymphadenopathy

Haematological: At least $50 \%$ mononuclear cells (lymphocytes and monocytes) and atypical cells

Serological: Positive heterophil antibody test after absorption. A fourfold or greater rise in EBVCA IgG. Detection of EBVCA IgM.

\section{Subjects and Methods}

Initial sera were obtained from:

(1) 469 boys already in school for at least one year at Received for publication 2 July 1975. the beginning of the trial in October 1970, and 80 के more such boys in November 1971;

(2) approximately 100 new boys aged 11 to 12 years each year from 1970 to 1974 ;

(3) 94 staff, in either 1970 or 1971.

Retest sera were obtained from:

(4) 145 boys presenting in the school infirmary as cases of influenza and 34 boys presenting as 울 cases of infectious mononucleosis;

(5) 578 boys retested in November from one to three years after the initial specimen.

Haematological and clinical records were kept on all cases of illness resembling infectious mononucleo- $\dot{0}$ sis using a data sheet itemizing information relevant to the diagnostic criteria.

Sera were tested for EBVCA IgG at a dilution of 13 in 8 by the indirect immunofluorescence test des-윽 cribed by Sumaya et al (1975) except that serum and $\square$ conjugate were allowed to react for a full 60 minutes. Those from suspect cases of infectious mononucleosis $N$ were titrated if found positive at 1 in 8 . Sera from suspect cases were also tested for EBVCA IgM and ${ }^{N}$ heterophil antibody. Heterophil antibody tests were $\tilde{\omega}^{N}$ all performed at the Public Health Laboratory and Department of Microbiology at the Central Middlesex Hospital, London. Procedures concerning cell $\stackrel{\varnothing}{\varnothing}$ lines, fluorescence reagents and techniques, illumina- $\stackrel{?}{+}$ tion system, and criteria for recording results were as 0 described by Edwards and McSwiggan (1974).

Results

Laboratory results are presented in tables I to III. Table I shows the overall results of 1050 boys tested 


\begin{tabular}{|c|c|c|c|c|c|c|c|c|c|c|c|c|c|c|c|c|c|c|}
\hline & \multicolumn{3}{|c|}{1970} & \multicolumn{3}{|c|}{1971} & \multicolumn{3}{|c|}{1972} & \multicolumn{3}{|c|}{1973} & \multicolumn{3}{|c|}{1974} & \multicolumn{3}{|c|}{ Total } \\
\hline & Teste & $\begin{array}{l}\text { dPosi- } \\
\text { tive } \\
\text { No. }\end{array}$ & $\%$ & Teste & $\begin{array}{l}\text { dPosi- } \\
\text { tive } \\
\text { No. }\end{array}$ & $\%$ & Test & $\begin{array}{l}\text { dPosi- } \\
\text { tive } \\
\text { No. }\end{array}$ & $\%$ & Teste & $\begin{array}{l}\text { d Posi- } \\
\text { tive } \\
\text { No. }\end{array}$ & $\%$ & Test & $\begin{array}{l}d \text { Posi- } \\
\text { tive } \\
\text { No. }\end{array}$ & $\%$ & Tested & $\begin{array}{l}\text { d Posi- } \\
\text { tive } \\
\text { No. }\end{array}$ & $\%$ \\
\hline $\begin{array}{l}\text { Boys } \\
\text { New intake } \\
\left(11-12 \mathrm{yr}^{1}\right)\end{array}$ & 84 & 33 & 39 & 88 & 28 & 35 & 90 & 27 & 30 & 111 & 42 & 38 & 88 & 33 & 38 & 461 & 163 & 35 \\
\hline $\begin{array}{l}\text { Already in school } \\
(12-18 \mathrm{yr})\end{array}$ & 469 & 158 & 34 & 80 & 32 & 40 & - & - & - & - & - & - & 40 & 13 & 33 & 589 & 203 & 34 \\
\hline Total boys & 553 & 191 & 35 & 168 & 60 & 36 & 90 & 27 & 30 & 111 & 42 & 38 & 128 & 46 & 36 & 1050 & 366 & 35 \\
\hline Staff & & & & & & & & & & & & & & & & 94 & 69 & 73 \\
\hline
\end{tabular}

Table I Results on INITIAL tests for EBV antibody (IgG) in boys admitted to the survey each year

${ }^{1}$ A few 13 years

\begin{tabular}{lll}
\hline Year & $\begin{array}{l}\text { Heterophil Antibody } \\
\text { Negative } \\
(I)\end{array}$ & $\begin{array}{l}\text { Heterophile Antibody } \\
\text { Positive } \\
(2)\end{array}$ \\
\hline $1970-71$ & 3 & 2 \\
$1971-72$ & 5 & 3 \\
$1972-73$ & 5 & 4 \\
$1973-74$ & 8 & 2 \\
Totals & 21 & $11+2^{1}$ \\
\hline
\end{tabular}

Table II Investigation of 34 patients for infectious mononucleosis over four years

${ }^{1}$ Two boys from whom no pre-illness specimen was available

$\begin{array}{llll}\hline \text { Year } & \begin{array}{l}\text { Conversion } \\ \text { with } \\ \text { Infectious } \\ \text { Mononucleosis }\end{array} & \begin{array}{l}\text { Conversion without Ilness } \\$\cline { 2 - 4 } \\ \text {$\left.No. of Originally }\end{array} \\ \hline 1970-71 & 2 & 253 & \begin{array}{l}\text { No. Found } \\ \text { Positive }\end{array} \\ 1971-72 & 3^{1} & 106 \\ 1972-73 & 4 & 164 \\ 1973-74 & 2 & 200\left\{\begin{array}{l}143 \text { routine } \\ 21 \text { influenza cases } \\ 76 \text { routine } \\ 124 \text { influenza cases }\end{array}\right. & 7 \\ \text { Totals } & 11 & 723\end{array}\right\}$

Table III Changes observed from negative to positive for EBV antibody $(I g G)$

In this year there were also two cases of infectious mononucleosis in boys from whom no pre-illness specimen had been taken.

for the first time between 1970 and 1974. Of these boys, $35 \%$ were found to be positive for EBVCA IgG. There was no significant difference between boys who had been in the school for a varying number of years (12-18 years old) and boys of the new intakes (11 and 12 years old, with a very few 13-yearolds).

Only 103 of the boys at the time of initial testing were 17 or 18 years old and of these $32(31 \%)$ had antibody. Of the 94 staff tested in 1970 and 1971, 69 were found to have antibody $(73 \%)$. This rate corresponds with that of students leaving the university
(Public Health Laboratory Service, unpublished).

From November 1970 to October 1974, 34 boys were investigated as possible cases of infectious mononucleosis (table II). Of the 21 boys in column 1 seven already had EBVCA IgG at at least a 1 in 32 dilution before illness. Thirteen had no EBVCA IgG at a dilution of 1 in 8 either before, during or after illness. One boy who had EBVCA IgG at onset had not had a pre-illness specimen taken. In none of the specimens from these boys was EBVCA IgM or heterophil antibody detected. All these results indicate that these cases were not infectious mononucleosis. Column 2 includes 11 boys whose sera were negative in the EBVCA IgG test at 1 in 8 before illness and were positive at 1 in 32 or more during the illness. The other two boys had a titre of 1 in 32 during illness but had had no pre-illness specimen taken. In sera from 12 boys EBVCA IgM and heterophil antibody were detected. The thirteenth boy was ill in the holidays. His serum tested before illness was negative for EBVCA IgG and the specimen taken on return to school was positive. A specimen taken at home during the illness gave a positive heterophil antibody result but was not available to us for EBVCA IgM test and the post-illness specimen at school was already negative in this test. These data on these 13 cases confirm a diagnosis of infectious mononucleosis.

Complete clinical records were available for 12 of the 13 in the infectious mononucleosis (IM) group and for 16 of the 21 who did not have the disease (non-IM). They show some differences between the groups. All 12 of the IM group had over $50 \%$ of mononuclear cells (lymphocytes and monocytes) and seven cases over $70 \%$ in the white cell count. Of the 16 recorded in the non-IM group, only three had slightly over $50 \%$ mononuclear cells. Abnormal mononuclear cells were recorded in both groups in all 12 IM cases and in only three of the 16 non-IM. Enlarged glands in areas other than the cervical 
chain were recorded in 11 of the IM cases but only two of the non-IM cases had glands enlarged in other areas, one in the inguinal region and the other in the axilla. It must be remembered that the nonIM cases continued to be investigated because of their presenting symptoms when they first saw the medical officer. Often it was quite apparent to him within the next few days that they were not cases of IM but tests were completed in most cases.

There are normally about 800 boys in the school, approximately 130 leaving and being replaced each autumn. Thirteen cases of IM occurred during a period of four years. A steady rate of two to five cases a year occurred, indicating that there was no outbreak at any time. Table III shows the number of conversions from negative to positive EBVCA IgG occurring with and without illness resembling IM. Unfortunately, all the boys were not retested each year because the sera taken were determined by the influenza vaccine trial requirements so the conversion rate of all the initially negative boys is not known. A total of 19 silent conversions were found over four years from 723 retests. Looking back through infirmary and holiday 'Temporary Resident' records of these boys, symptoms compatible with IM were recognized for four boys at some time during the period preceding the positive sample, in two cases during the school holidays. All four had pyrexial episodes with sore throat, three had enlarged cervical glands, and in two of them a diagnosis of tonsillitis was made. As samples were not taken at the time because the symptoms did not suggest a diagnosis of IM, it is not possible to make a diagnosis in retrospect. It is interesting that the conversion serum from one boy gave a positive monospot reaction.

Each boy whose initial serum was negative was closely studied. The number of months which elapsed until his serum became positive or until his final specimen was taken was recorded. The number of such boys was 414 and the total months of surveillance 8810, an average of 21 months per boy. There were 30 conversions recorded in the 8810 pupil-months observed, or one for each 294 months. A similar study at three universities showed that in 9781 student-months observed there were 151 conversions, or one for each 65 months, a rate $4 \frac{1}{2}$ times greater.

\section{Discussion}

Antibody to EBVCA is detected by the indirect immunofluorescence test first described by Henle in 1966. This antibody can be detected within a few days of infection with $\mathrm{EB}$ virus and thereafter persists throughout life.
From large-scale surveys of different ages and communities it has been found that EB virus (IgG) antibody is present and therefore infection has occurred by the age of 2 in $75-80 \%$ of children in underveloped countries and overcrowded or lower socio-economic communities of more advanced countries (Kafuko et al, 1972; Porter et al, 1969; Tischendorf et al, 1970).

In communities of higher socio-economic levels, or where close social mixing is minimal, less than $40 \%$ of children are infected before the age of 4 (Pereira et al, 1969; Tischendorf et al, 1970; Demissie and Svedmyr, 1969; Henle and Henle, 1970). Niederman et al (1970) and Hallee et al (1974) in New England and the University Health Physicians and Public Health Laboratories (1971) in the United Kingdom have shown that in the Military Academy and the universities they studied only 57$64 \%$ of students had antibody on entry to the course. Of those negative on entry in the United Kingdom university study, $12 \%$ acquired antibody during the first academic year ( 7 months) and $75-80 \%$ of those graduating were antibody positive. Of those acquiring antibody nearly half had a classic attack of IM.

In this study, of the 461 boys coming into a boarding school aged between 11 and 13, the proportion with EBV antibody was $35 \%$. There was little annual variation in this figure. This proportion is similar to but slightly lower than the $39 \%$ found by Pereira et al in their 5-14 years age group. The school admits boys from all social classes but $54 \%$ of the 1969-71 entries were from the Registrar General's social classes I and II (Cox and Hoskins, 1973). Of the 1970-72 entries, $28 \%$ had come from private preparatory schools as either day boys or boarders. Both these factors would tend to favour a lower proportion of boys with antibody than in the general population.

The school and universities differ in that the school pupils are all male whereas the university students are mixed. The school community of 800 is smaller than the university community and, being a board- o ing school, there is much less admixture with the $N$ general population. This may be so even in the holidays. Students spend three to four years at the university whereas the boys tend to remain at school for six to seven years. Thus in the university at any time there are likely to be more recently infected $\stackrel{\Phi}{\rightarrow}$ persons in their midst, some of whom may be longterm dispersers of virus (Miller et al, 1973).

There is a discrepancy between the school leavers at 17 to 18 , of whom $31 \%$ were antibody positive in $\frac{\vec{D}}{8}$ 1970 , and the university entrants, of whom $57 \%$ 응 were positive. This discrepancy may be exaggerated because the 17-18 age group sampled in the school 
was small (103). Other possible explanations are that the schoolboys acquire infection between leaving school and entering the university. This period may be as much as a year. Alternatively, the boys from this type of school may constitute the least positive of the student range balanced by boys and girls from mixed day schools in high-density areas. It is known that female students have a higher rate of antibody at entry than male students (Public Health Laboratory Service, unpublished).

Typical IM exhibiting the required clinical, haematological, and antibody criteria was found among boys of all ages but nine of the 13 cases were 15 years or more. Again, silent conversion occurred at all ages but, of the 19,12 were 14 years or less. However, more re-sampling sera came from the younger age group.

We wish to thank the Wellcome Research Laboratories for providing the specific anti-human FITC conjugate for the immunofluorescence test: $\mathrm{Dr}$ Earl of the Redhill Group Laboratory, and Dr Pollock, Dr Miller, and Mrs Smith, of the Epidemiology Research Laboratory, for provision and collection of sera and pupil records; Dr McSwiggan and Miss Jordan, of the Central Middlesex Hospital, London, for the heterophil antibody results; and Mrs Joy, of the Virus Reference Laboratory, for help in the preparation of this report.

\section{References}

Cox, M. and Hoskins, T. (1973). Collaboration between psychiatrist and medical officer in a boys' boarding school. Practitioner, 210, 209-216.

Demissie, A. and Svedmyr, A. (1969). Age distribution of antibodies to EB virus in Swedish females as studied by indirect immunofluorescence on Burkitt cells. Acta path. microbiol. scand., 75, 457-465.

Edwards J. M. B. and McSwiggan, D. A. (1974). Studies on the diagnostic value of an immunofluorescence test for EB virus-specific IgM. J. clin. Path., 27, 647-651.

Evans, A. S. (1969). Infectious mononucleosis: recent developments. GP (Kansas), 40, (5), 127-134.

Hallee, T. J., Evans, A. S., Niederman, J. C., Brooks, C. M., and Voegtly, J. H. (1974). Infectious mononucleosis at the United States Military Academy: a prospective study of a single class over four years. Yale J. Biol. Med., 47, 182195.

Henle, G. and Henle, W. (1970). Observations on childhood infections with the Epstein-Barr virus. J. Infect. Dis., 121, 303-310.

Kafuko, G. W., Henderson, B. E., Kirya, B. G., Munube, G. M. R., Tukei, P. M., Day, N. E., Henle, G., Henle, W., Morrow, R. H., Pike, M. C., Smith, P. G., and Williams, E. H. (1972). Epstein-Barr virus antibody levels in children from the West Nile district of Uganda. Lancet, 1, 706709.

Miller, G., Niederman, J. C., and Andrews, L. (1973). Prolonged oropharyngeal excretion of Epstein-Barr virus after infectious mononucleosis. New Engl. J. Med., 288, 229-232.

Niederman, J. C., Evans, A. S., Subrahmanyan, L., and McCollum, R. W. (1970). Prevalence, incidence and persistence of EB virus antibody in young adults. New Engl. J. Med., 282, 361-365.

Pereira, M. S., Blake, J. M., and Macrae, A. D. (1969). EB virus antibody at different ages. Brit. med. J., 4, 526-527.

Porter, D. D., Wimberly, I., and Benyesh-Melnick, M.7 (1969). Prevalence of antibodies to EB virus and other herpes viruses. J. Amer. med. Ass., 208, 1675-1679.

Sumaya, C. V., Henle, W., Henle, G., Smith, M. H. D., and LeBlanc, D. (1975). Seroepidemiologic study of EpsteinBarr virus infections in a rural community. J. infect. Dis., 131, 403-408.

Tischendorf, P., Shramek, G. J., Balagtas, R. C., Deinhardt, F., Knospe, W. H., Noble, G. R., and Maynard, J. E. (1970). Development and persistence of immunity to Epstein-Barr virus in man. J. infect. Dis., 122, 401-409.

University Health Physicians and Public Health Laboratories (1971). Infectious mononucleosis and its relationship to EB virus antibody. Brit. med. J., 4, 643-646. 